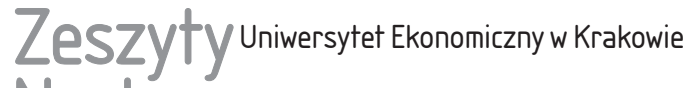 Naukowe
}

$8(944)$

ISSN 1898-6447

Zesz. Nauk. UEK, 2015; 8(944): 45-55

DOI: 10.15678/ZNUEK.2015.0944.0804

\section{Małgorzata Adamska-Chudzińska}

Katedra Psychologii i Dydaktyki

Uniwersytet Ekonomiczny w Krakowie

\section{Zaangażowanie organizacyjne pracowników jako źródło uczestnictwa w organizacji}

\section{Streszczenie}

W artykule dokonano przeglądu koncepcji zaangażowania organizacyjnego w perspektywie historycznej. Zwrócono uwagę na różnorodność podejść i specyfikę dokonań w poszczególnych okresach. Wyróżniono model zaangażowania organizacyjnego zaproponowany przez J. Mayera i N. Allen jako zasadniczy dla podstawowego nurtu współczesnych badań nad zaangażowaniem. Model zawiera rozróżnienie trzech niezależnych komponentów zaangażowania organizacyjnego, czyli emocjonalnego, racjonalnego i normatywnego. Każdy z nich wiąże się z innym stanem psychicznym i odpowiadającym mu zachowaniem w pracy. Możliwe jest na tej podstawie wskazanie trzech głównych uzasadnień uczestnictwa w organizacji (chęć, konieczność, powinność), a zarazem związku pomiędzy tymi powodami a rodzajem zaangażowania w jej działalność. W konsekwencji podjętych rozważań zaakcentowano zgodność większości badaczy, pomimo różnorodności podejść, w uznawaniu roli emocjonalnego aspektu zaangażowania organizacyjnego jako decydującego o autentyczności i sile identyfikacji z organizacją.

Słowa kluczowe: zaangażowanie organizacyjne, zaangażowanie emocjonalne, uczestnictwo w organizacji, model J. Mayera i N. Allen.

* Artykuł powstał w ramach realizacji tematu badawczego nr 071/WE-KPD/01/2015/S/S071 na Wydziale Ekonomii i Stosunków Międzynarodowych Uniwersytetu Ekonomicznego w Krakowie. 


\section{Wprowadzenie}

Zaangażowanie organizacyjne to kategoria, która pozwala zrozumieć różnorodność zachowań ludzi w organizacji. Określony rodzaj i stopień zaangażowania determinuje zakres wysiłku wkładanego w pracę, umotywowania do współdziałania z innymi, przedsiębiorczości i innowacyjności, a w rezultacie określa poziom efektywności i jakości pracy. Wiedza na temat zaangażowania organizacyjnego jawi się jako kluczowa dla menedżerów XXI w., którzy uznali priorytet zasobów ludzkich nad pozostałymi zasobami organizacyjnymi. Zgodnie z najnowszymi koncepcjami zarządzania możliwości tkwiące w osobowości i kompetencjach pracowników decydują o efektywności wykorzystania zasobów finansowych i materialnych. Potencjał możliwości ludzkich przy zachowaniu podmiotowego podejścia do pracowników jest nie tylko unikalny z uwagi na niepowtarzalny charakter osobowych wyznaczników działania, ale również nieograniczony ze względu na społeczny wymiar kontekstów działania.

Stąd pojawia się potrzeba podejmowania działań, które sprowadzać się będą nie tylko do zewnętrznego motywowania ludzi, ale także wyzwalać będą ich wewnętrzne, wieloaspektowe zaangażowanie. Wzrost efektywności organizacji jest bowiem możliwy dzięki aktywności przedsiębiorczych, pełnych energii i entuzjazmu, oddanych pracy i ciągle rozwijających się pracowników. Można by oczekiwać, że stosowne wykorzystanie wiedzy o czynnikach kształtujących zaangażowanie organizacyjne pozwoli współczesnym menedżerom uporać się z wyzwaniami konkurencyjności na rynku. Tymczasem wiedza ta nie stanowi uporządkowanego kompendium opartego na konkretnych, ujednoliconych zasadach. Zaangażowanie jest kategorią wielowymiarową, nastręczającą wielu trudności podczas badań i analiz, w których odnoszona jest do różnych zachowań pracowniczych, np. wyników pracy, fluktuacji, satysfakcji, zachowań obywatelskich [Johnson, Groff i Taing 2009].

Celem artykułu jest przedstawienie koncepcji zaangażowania organizacyjnego w perspektywie historycznej i wykazanie związku pomiędzy powodami uczestnictwa w organizacji a rodzajem zaangażowania w jej działalność. W konsekwencji podjętych rozważań akcent położony został na emocjonalny typ zaangażowania jako szczególnie pożądany we współczesnych zmiennych uwarunkowaniach wymagających autentycznego przywiązania do organizacji i ciągłego kreowania nowych rozwiązań. 


\section{Koncepcje zaangażowania pracowników w perspektywie historycznej}

Zaangażowanie organizacyjne stanowi szczególny rodzaj postaw pracowniczych, odmienny od motywacji czy zadowolenia z pracy. Wynika z autentycznej chęci uczestnictwa w organizacji, co powoduje, że zaangażowanie wpływa na zachowanie pracowników niezależnie od innych, konfliktowych motywów i postaw. W tym sensie zaangażowanie w większym stopniu niż inne postawy odpowiada za efektywność działań, dokonywanie korekt zapewniających realność tych działań, jak i formułowanie propozycji mogących stanowić zaczątki większych strategii.

Zwiększanie zaangażowania pracowników od dawna stanowi przedmiot zainteresowania zarówno w teorii, jak i w praktyce zarządzania zasobami ludzkimi. Początki tego zainteresowania sięgają lat 60. XX w., kiedy to H. Becker [1960, s. 32-42] przedstawił jedną z najwcześniejszych koncepcji zaangażowania, tzn. koncepcję zakładów dodatkowych. Autor przyjął, że zaangażowanie stanowi indywidualną dyspozycję do angażowania się w spójny ciąg działań, prowadzących do określonego celu. Charakterystyczne dla podejścia H. Beckera było wiązanie zaangażowania z oczekiwaniem przyszłych korzyści lub utrzymaniem dotychczasowych, np. specyficznych umiejętności, pozytywnych relacji ze współpracownikami, nagród, specjalnych uprawnień. Koncepcja ta wyraźnie nawiązuje do jednego z mechanizmów ludzkiego działania, zgodnie z którym skłonność do podtrzymywania danej aktywności pozostaje w związku z przyczynami, których nie brano pod uwage, gdy rozpoczynano dane działanie [Szpik i Klincewicz 2008, s. 471-492]. Zaprezentowana w koncepcji wizja zaangażowanego pracownika ukazywała go jako chłodno kalkulującego podejmowane decyzje i liczącego na przyszłe nagrody. H. Becker wskazał również na bezpośredni związek pomiędzy zaangażowaniem a fluktuacją, co zostało wielokrotnie potwierdzone w późniejszych badaniach i nadal stanowi jeden z podstawowych związków, analizowanych przez badaczy zaangażowania organizacyjnego.

Intensywny wzrost zainteresowania problematyką zaangażowania nastąpił w latach 80. XX w. Zapoczątkował go R.T. Mowday, który wraz ze współpracownikami [Mowday, Porter i Steers 1982] opracował koncepcję zaangażowania wynikającego z psychicznego przywiązania pracownika do organizacji. Zespół R.T. Mowdaya definiował zaangażowanie jako indywidualne absorbowanie pracownika organizacją i identyfikację z nią. Istotnym efektem współpracy członków Zespołu było opracowanie Kwestionariusza zaangażowania organizacyjnego, który składał się pytań odnoszących się do trzech potencjalnych obszarów zaangażowania pracownika. Tworzyły je: 1) akceptacja i wiara w cele i wartości organizacji, 2) chęć ponoszenia wysiłków na rzecz organizacji, 3) siła pragnienia 
pozostania członkiem organizacji. Pomimo uwzględnienia tych trzech obszarów autorzy traktowali zaangażowanie jako zjawisko jednowymiarowe, tzn. określali pracownika jako zaangażowanego lub niezaangażowanego. Uniemożliwiło to wyjaśnianie bardziej złożonych zachowań ludzi w organizacjach i stało się przedmiotem krytycznej polemiki.

Jednowymiarowość powyższego podejścia została zakwestionowana w połowie lat $80 . \mathrm{XX}$ w. przez dwa niezależne zespoły badawcze. Pierwszym byli Ch. O’Reilly i J. Chatman [1986], a drugi to zespół utworzony przez J. Meyera i N. Allen [1991]. Koncepcja zaproponowana przez Ch. O'Reilly'ego i J. Chatmana nie zdobyła dużej popularności. Stanowi jednak wkład do teorii zachowań organizacyjnych. Autorzy wskazali na związek zaangażowania z zachowaniami obywatelskimi polegającymi na dobrowolnym wykonywaniu działań na rzecz organizacji, które nie są związane z formalnymi obowiązkami i nie są bezpośrednio nagradzane. Przykładami takich zachowań może być: pomoc merytoryczna mniej doświadczonym kolegom lub chęć zostania po godzinach pracy, by skończyć w terminie dany projekt. Późniejsze badania potwierdziły istotność związku pomiędzy tego typu zachowaniami a zaangażowaniem organizacyjnym i znaczenie zachowań obywatelskich jako ważnego aspektu sukcesu organizacji. Z kolei, badania zrealizowane przez zespół J. Meyera i N. Allen wykazały złożoność zjawiska zaangażowania organizacyjnego i stworzyły podstawę wyjaśniania różnorodności zachowań ludzi w organizacjach. Zaproponowany przez autorów model zaangażowania traktowany jest jako zasadniczy dla podstawowego nurtu badań nad zaangażowaniem organizacyjnym.

W latach 90. XX w. znaczący wpływ na wyjaśnianie fenomenu zaangażowania wywarł W.A. Kahn. Zauważył, że zaangażowanie to stan psychiczny, który umożliwia pracownikom wyrażanie siebie podczas wykonywanej pracy. Zdefiniował zaangażowanie jako zaprzęgnięcie jaźni członków organizacji do wypełniania swojej roli w pracy [Kahn 1990]. Koncepcja W.A. Kahna oparta została na przekonaniu, że owo wyrażanie siebie w działaniu może zachodzić w trzech wymiarach: fizycznym, poznawczym i emocjonalnym. W.A. Kahn zakładał, że każdy z tych wymiarów może odrębnie charakteryzować zachowanie pracownika i osiągać różny poziom natężenia. Jednak dla powstania zaangażowania konieczne jest wystąpienie wszystkich wymiarów. Skupienie energii zarówno fizycznej, poznawczej, jak i emocjonalnej na wykonywanej pracy, daje efekt „,pochłonięcia” pracą. W.A. Kahn sformułował pięć warunków, od których zależy współwystępowanie wszystkich wymiarów: 1) poczucie psychologicznego bezpieczeństwa w pracy, 2) poczucie sensu i znaczenia roli zawodowej, 3) poczucie dostępności - adekwatności własnego potencjału do dobrego wykonania zadań, 4) postrzeganie organizacyjnego wsparcia i zgodności z wartościami organizacji, 5) wewnętrzne zobowiązanie (kontrakt) wzajemnej lojalności i sprawiedliwej wymiany. Koncepcja 
W.A. Kahna stała się dla wielu współczesnych przedsiębiorstw inspiracją do własnych badań polegających na poszukiwaniu czynników, dzięki którym wskazane warunki mogą być spełnione w danym przedsiębiorstwie.

\section{Model zaangażowania organizacyjnego J. Mayera i N. Allen}

Przełomową rolę $\mathrm{w}$ badaniu zaangażowania organizacyjnego odegrały prace J. Mayera i N. Allen [1991]. Badacze ci stworzyli metodologicznie poprawny model, na którym oparty został podstawowy nurt dalszych badań dotyczących zaangażowania organizacyjnego oraz jego związku z zachowaniami pracowników (rys. 1). Model J. Meyera i N. Allen rozróżnia trzy niezależne komponenty zaangażowania organizacyjnego, z których każdy wiąże się z innym stanem psychicznym i odpowiadającym mu zachowaniem w pracy, a mianowicie:

- emocjonalny - decyduje on o zaangażowaniu afektywnym i identyfikacji z wartościami organizacyjnymi. Odzwierciedla to, na ile pracownik wiąże swoją obecność $\mathrm{w}$ organizacji z autentycznym zainteresowaniem treścią wykonywanych czynności i możliwością urzeczywistniania walorów własnej osobowości (chce być w organizacji);

- racjonalny - wpływa na zaangażowanie trwania, czyli uświadomioną przez pracownika potrzebę kontynuowania pracy dla organizacji ze względu na pewne koszty i straty związane z odejściem z organizacji (dodatki za staż, specjalne uprawnienia $\mathrm{i}$ inne) oraz $\mathrm{z}$ ograniczonymi alternatywami na rynku pracy (potrzebuje być w organizacji);

- normatywny - wyznacza zaangażowanie normatywne, uwarunkowane przez normy społeczne oraz poczucie zobowiązania i lojalności (klimat pracy oparty na zaufaniu i wierności ustalonym wartościom i zasadom) pracownika wobec organizacji (czuje, że powinien pozostać w organizacji).

Wskazane rozróżnienie komponentów / typów zaangażowania organizacyjnego umożliwia wskazanie trzech możliwych uzasadnień uczestnictwa w organizacji (chęć, konieczność, powinność). Pracownik może być członkiem organizacji ze względu na: stan wewnętrznej identyfikacji z jej wartościami, poczucie konieczności wynikające $\mathrm{z}$ braku alternatywnych możliwości zatrudnienia, poczucie powinności ukształtowane $w$ toku wzajemnych relacji w organizacji. Pierwszy typ charakteryzuje się najsilniejszym wpływem na efektywność działań, nie można jednak jednoznacznie stwierdzić czy wzrost zaangażowania afektywnego zwiększa przywiązanie do organizacji i jak wpływa na decyzje o pozostawaniu $\mathrm{w}$ firmie. W tym aspekcie model w konfrontacji z ustaleniami empirycznymi nie daje wyczerpującej odpowiedzi. 


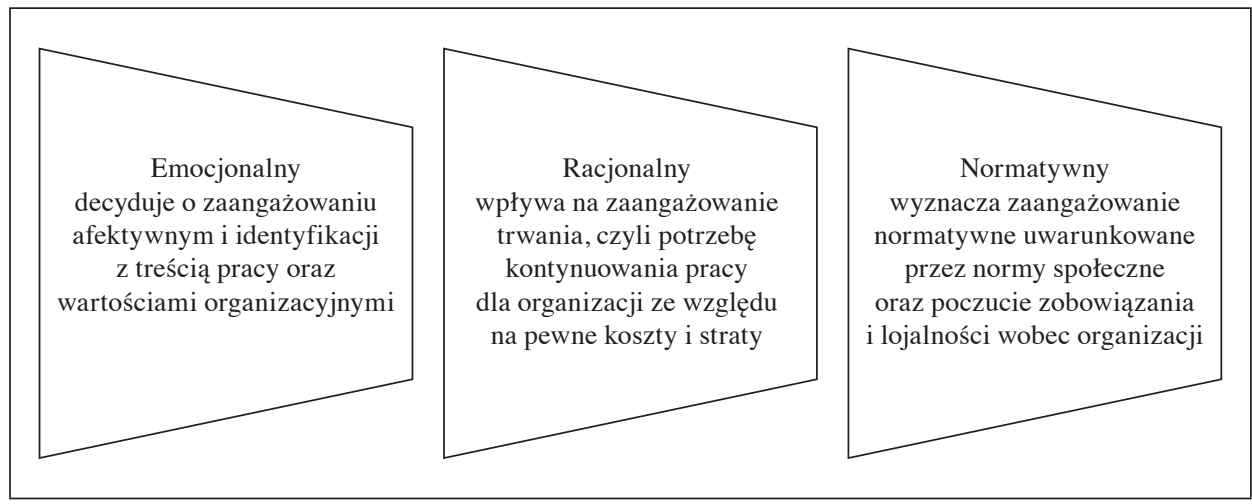

Rys. 1. Komponenty zaangażowania organizacyjnego

Źródło: opracowanie własne na podstawie: [Mayer i Allen 1991, s. 61-89].

Istotnym wyróżnikiem prezentowanej koncepcji jest możliwość wyjaśnienia na jej kanwie wielu paradoksów obserwowanych w zachowaniach pracowników, na przykład dlaczego kluczowy pracownik, którego organizacja godziwie wynagradza i stwarza mu warunki rozwoju kariery, po uzyskaniu kolejnego awansu decyduje się zmienić pracodawcę. Model J. Mayera i N. Allen daje sposobność zinterpretowania takiego zachowania, mianowicie wraz z docenieniem osiągnięć pracownika wzrasta zapewne jego zaangażowanie afektywne, ale równocześnie może dojść do znacznego obniżenia zaangażowania trwania. W takiej sytuacji wzrasta bowiem pozycja pracownika na rynku pracy i poziom jego aspiracji, a zarazem atrakcyjność dla innych pracodawców. Ten specyficzny układ obu typów zaangażowania może stać się czynnikiem wpływającym na decyzję o odejściu z organizacji. Każdemu rodzajowi zaangażowania odpowiada inny stan psychiczny, który powstaje na skutek odmiennych uwarunkowań i w różny sposób wpływa na zachowanie pracownika. W rozważanym przykładzie organizacja mogłaby zgodnie z założeniami autorów modelu wpłynąć na decyzję pracownika poprzez tworzenie wysokiego poziomu zaangażowania normatywnego, czyli poprzez budowanie lojalności i poczucia zobowiązania wobec organizacji. Jest to możliwe za pośrednictwem kultury organizacyjnej kształtowanej na podstawie fundamentalnych wartości społecznych (np. zaufanie, uczciwość, odpowiedzialność, sprawiedliwość) i wynikających z nich norm organizacyjnego postępowania (np. norma wzajemności, norma konsekwencji).

Wśród czynników wpływających na zaangażowanie organizacyjne i stymulujących określony typ zaangażowania autorzy prezentowanego modelu wymieniają:

- w zakresie zaangażowania afektywnego: cechy osobowości, dopasowanie cech osobowości i środowiska pracy, warunki pracy (wykorzystywanie różnorodnych umiejętności, ambitne zadania, partycypacja w procesie decyzyjnym), 
poczucie sprawiedliwego traktowania, cechy organizacji (polityka firmy wobec pracowników, sposób komunikowania zmian dotyczących pracowników), doświadczenia zawodowe (poczucie komfortu, poczucie kompetencji),

- w zakresie zaangażowania trwania: tzw. zakłady dodatkowe (korzyści i przywileje organizacyjne) i inne dobra niedostępne poza organizacją, brak alternatyw zatrudnienia, brak umiejętności przydatnych w innych organizacjach, wykonywanie roli żywiciela rodziny,

- w zakresie zaangażowania normatywnego: inwestycje organizacji na rzecz pracownika, doświadczenia pracownika związane z internalizacją norm społecznych i organizacyjnych (socjalizacja), zgodność kultury organizacyjnej z kulturą społeczności lokalnej.

W modelu J. Mayera i N. Allen zawarte jest założenie, że związki pomiędzy czynnikami wpływu na stan zaangażowania a typem zaangażowania i skutkami poszczególnych typów zaangażowania widocznymi w zachowaniu pracowników mają charakter przyczynowo-skutkowy. Jednak prowadzone badania pozwoliły jedynie na potwierdzenie współwystępowania tych zmiennych [Szpik i Klincewicz 2008]. Było to skutkiem typowego ograniczenia tkwiącego w naturze badań ankietowych wykorzystujących jedynie korelacje zmiennych i nie dało wystarczających podstaw do generalizowania wniosków o przyczynach i skutkach badanych zjawisk. Sytuacja taka stwarza potrzebę podejmowania kolejnych badań służących weryfikowaniu wpływu poszczególnych czynników lub działań sprzyjających ich wystąpieniu na rodzaj i stan zaangażowania organizacyjnego.

\section{Emocjonalny aspekt zaangażowania organizacyjnego}

Współczesne badania nad zaangażowaniem organizacyjnym nadal ukierunkowane są na poszukiwanie bądź związków z wynikami ekonomicznymi organizacji, bądź czynników stymulujących poziom natężenia zaangażowania. Mimo zaawansowania działań badawczych dotychczas nie wypracowano jednoznacznego stanowiska w ujmowaniu tego zjawiska. Prowadzone badania mierzące w różny sposób rozumiane zaangażowanie są ze sobą praktycznie nieporównywalne, co powoduje, że nie można wskazać uniwersalnego wskaźnika czy miary zaangażowania pracowników [Mrówka 2010, s. 405-416].

Pomimo znacznej różnorodności podejść stosowanych we współczesnych badaniach nad zaangażowaniem organizacyjnym większość badaczy zgadza się, że dla jego powstania i rozwoju niezbędne jest nawiązanie pozytywnej relacji pomiędzy pracownikiem a organizacją [Robinson, Perryman i Hayday 2004] oraz jej doświadczanie w postaci przeżywanych emocji. Taki sposób ujmowania 
zaangażowania, widoczny już we wcześniejszych koncepcjach W.A. Kahna oraz J. Mayera i N. Allen, ujawnia skupienie na emocjonalnym jego podłożu.

Warto zauważyć, że postrzeganie emocji w organizacji pierwotnie dotyczyło sposobów przekształcania i ujawniania emocji przez pracowników tak, by były zgodne z rolą zawodową i oczekiwaniami organizacji. Wyjaśnia je koncepcja tzw. pracy emocjonalnej [Hochschild 2003], w której autorka opisuje mechanizmy powstawania zachowań, takich jak np. wymuszony uśmiech stewardes czy kelnerów przy obsłudze klientów. Współczesne koncepcje zaangażowania organizacyjnego znacznie poszerzają to podejście. Badacze podkreślają, że nie chodzi już o to, by pracownik dostosowywał i ujawniał w pracy emocje zgodne z rolą zawodową. Istotne jest wykształcenie pozytywnych emocji pracownika wobec organizacji prowadzących do osobistego przywiązania i emocjonalnej identyfikacji z nią. Relacje pracownika z organizacją można wówczas interpretować jako ciąg interakcji, w których obie strony wzajemnie respektują swoje potrzeby i doprecyzowują w działaniu swoje uprawnienia i reguły, zawarte w umowach o pracę i regulaminach organizacyjnych [Daniel 2004].

Zasadniczym elementem tak ujmowanego zaangażowania jest wiązanie działań pracownika z jego przekonaniami. Kwestia takich powiązań jednostki z jej działaniami ujawnia się poprzez trzy główne cechy charakteryzujące silne zaangażowanie organizacyjne [Cohen 2007, s. 338]:

- pełną akceptację celów i wartości organizacyjnych,

- wysoką skłonność do podejmowania dużego wysiłku na rzecz organizacji,

- silne pragnienie przynależności do organizacji.

Ujmowanie zaangażowania organizacyjnego w kategoriach osobistej identyfikacji z celami i wartościami organizacyjnymi, gotowością do działania na rzecz organizacji i potrzebą kontynuowania uczestnictwa w niej jest często zaznaczanym elementem w definiowaniu tego zjawiska. Badacze traktują je wręcz jako uporczywy, pozytywny stan afektywno-motywacyjny odczuwany przez pracowników i charakteryzujący się wysokim poziomem pobudzenia i zadowolenia [Roberts i Davenport 2002]. Podkreśla się, że tego typu zaangażowanie stanowi o tym, w jakim stopniu pracownicy identyfikują się i włączają w życie organizacji, wykorzystując własne kompetencje do osiągania jej celów [Pocztowski 2008, s. 429]. Jest ono traktowane jako psychologiczna siła, która łączy pracowników z organizacjami i czyni odejście z nich mniej atrakcyjnym [Johnson, Groff i Taing 2009].

Emocjonalna konstrukcja zaangażowania organizacyjnego ujawnia się także w pracach W. Schaufeliego i współpracowników [2002]. Autor utrzymuje, że jest to stan, na który składa się doświadczanie przez pracownika wigoru podczas wykonywania pracy, oddanie się tej pracy oraz zaabsorbowanie nią. Wigor wyjaśniany jest jako doświadczanie wysokiego poziomu energii i wytrzymałości 
podczas pracy. Umożliwia wykonywanie pracy nawet w obliczu pojawiających się trudności i przeszkód. Oddanie się pracy wiąże się z odczuciem jej istotnego znaczenia oraz doświadczaniem entuzjazmu i dumy podczas jej wykonywaniam, natomiast zaabsorbowanie pracą polega na pełnej koncentracji na czynnościach pracy i pogrążeniu w ich wykonywaniu. To właśnie aspekt emocjonalny zaangażowania decyduje o tym, czy pracownik będzie bardziej przedsiębiorczy, kreatywny i częściej poszukiwać będzie innowacyjnych rozwiązań problemów organizacyjnych [Gallup Study 2012]. Stwarza to duże prawdopodobieństwo zwiększania efektywności działań i osiąganych wyników, a ostatecznie prowadzi do wzrostu wartości organizacji na rynku.

\section{Podsumowanie}

Dokonany przegląd koncepcji i rozumienia zaangażowania organizacyjnego pozwala na stwierdzenie, że pomimo różnorodności stosowanych podejść badawczych w zasadzie istnieje zgodność w przyjmowaniu jego emocjonalnego kontekstu i traktowaniu jako stanu psychicznego lub postawy wobec czynności zawodowych. Ze względów teoretycznych i praktycznych wydaje się to właściwe, gdyż wskazuje na związek zaangażowania pracownika z jego zdolnością do działań wysoceefektywnych, przedsiębiorczych, kreatywnych i innowacyjnych, a nawet warunkujących przekraczanie dotychczasowych standardów. Można zatem przyjąć, że zaangażowanie organizacyjne jest specyficznym typem relacji pomiędzy pracownikiem i organizacją, która polega na wzajemnym zabsorbowaniu oraz wzajemnym budowaniu przywilejów i korzyści. Relacja taka może być rezultatem, zgodnie z modelem J. Mayera i N. Allen, ścierania się trzech typów zaangażowania: afektywnego, normatywnego i trwania. Dominacja aspektów emocjonalnych jest ujmowana jako najbardziej pożądana, gdyż ujawnia się w sile identyfikacji z organizacją i koncentracji na pracy, przez co stwarza duże prawdopodobieństwo stymulowania wyników ekonomicznych organizacji. Dalszej weryfikacji wymaga kwestia czy rzeczywiście zaangażowanie organizacyjne sprzyja osiąganiu wyższych rezultatów pracy, czy bardziej wpływa na inne zachowania pracownicze, takie jak stabilizacja zatrudnienia. Na podstawie dokonanego przeglądu stanowisk teoretycznych trudno także stwierdzić czy jest ono efektem warunków pracy (w tym kultury organizacyjnej) stwarzanych przez menedżerów, czy może jedynie cech osobowości posiadanych przez pracowników. Potwierdzone zostało znaczenie czynnika emocjonalnego, który wraz z normą wzajemności w relacjach organizacyjnych traktowany jest jako istotne źródło zaangażowania organizacyjnego. 


\section{Literatura}

Becker H.S. [1960], Notes on the Concept of Commitment, „American Journal of Sociology", vol 66(1), http://dx.doi.org/10.1086/222820.

Cohen A. [2007], Commitment Before and After: An Evaluation and Reconceptualization of Organizational Commitment, „Human Resource Management Review”, vol. 17(3), http://dx.doi.org/10.1016/j.hrmr.2007.05.001.

Daniel [2004], Engagement Policies Boost Pre-tax Profits at Nationwide, „Personnel Today", nr 1-7.

Gallup Study [2012], Engaged Employees Inspire Company Innovation, „Gallup Busines Journal", http://businessjournal.gallup.com/kontent/24880/gallup study-engaged-employees-inspire-company.aspx (dostęp:11.09.2013).

Hochschild A.R. [2003], The Managed Heart: Commercialization of Human Feeling, University of California Press, Berkeley.

Johnson R.E., Groff K.W., Taing M.U. [2009], Nature of the Interactions among Organizational Commitments: Complementory, Competitive or Synergistic? „British Journal of Management”, vol. 20, http://dx.doi.org/10.1111/j.1467-8551.2008.00592.x.

Kahn W.A. [1990], Psychological Conditions of Personal Engagement and Disengagement at Work, ,Academy of Management Review”, nr 33.

Mayer J., Allen N. [1991], Tree Component Conceptualization on Organizational Commitment, „Human Resource Management Review”, nr 1/1.

Mowday R.T., Porter L., Steers R.H. [1982], Employee-Organization Linkages, the Psychology of Commitment, Absenteeism and Turnover, Academic Press, London.

Mrówka R. [2010], Pojęcie zaangażowania pracowników we współczesnych naukach ekonomicznych i praktyce gospodarczej [w:] Nauki ekonomiczne w'świetle nowych wyzwań gospodarczych, red. R. Bartkowiak, J. Ostaszewski, Oficyna Wydawnicza SGH, Warszawa.

O'Reilly C.A., Chatman J. [1986], Organizational Commitment and Psychological Attachment: The Effects of Compliance, Identification and Internalization on Prosocial Behavior, ,Journal of Applied Psychology”, vol. 71(3), http://dx.doi. org/10.1037/0021-9010.71.3.492.

Pocztowski A. [2008], Zarzqdzanie zasobami ludzkimi, PWE, Warszawa.

Roberts D.R., Davenport T.O. [2002], Job Engagement: Why It's Important and How to Improve It [w:] Employment Relation Today, Willey Periodicals, Autum.

Robinson D., Perryman S., Hayday S. [2004], The Drivers of Employee Engagement, Report 408. Institute for Employment Studies, April http://www.wellbeing4business. co.uk/docs/Article\%20-\%20Engagement\%20research.pdf

Schaufeli W.B., Salanova M., Gonzàlez-Romaà V., Bakker A.B. [2002], The Measurement of Engagement and Burnout: A Two Sample Confirmatory Factor Analytic Approach, „Journal of Happiness Studies”, nr 3.

Szpik A., Klincewicz K. [2008], Nowe kierunki w zarzq̨dzaniu ludźmi-zaangażowanie organizacyjne [w:] Współczesne koncepcje zarzq̨dzania, red. M. Kostera, Wydawnictwo Akademickie i Profesjonalne, Warszawa. 


\section{The Organisational Engagement of Employees as a Source of Participation in the Organisation}

(Abstract)

The article reviews the concepts of organisational engagement from a historical perspective. It emphasises a diversity of approaches and the particular achievements in separate periods. A model of organisational engagement proposed by Mayer and Allen was chosen as best representing the basic trend of contemporary research on engagement. Their model includes differentiation of three independent components of organisational engagement - emotional, rational and normative. Each of them is connected with a different mental state, and a corresponding behaviour at work. Hence, it is possible to suggest three main justifications of participation in an organisation (willingness, necessity and duty) and thus there is a connection between those causes of behaviour and the type of engagement that occurs within it. The author stresses that the majority of scholars agree that the emotional aspect of engagement is key in producing authentic and strong identification with an organisation.

Keywords: organisational engagement, emotional engagement, participation in organisation, Mayer and Allen's model. 